\title{
Рославцева С.A.
}

Современное распространение постельных клопов в мире (обзор литературы)

DOI: https://dx.doi.org/10.33029/0016-9900-2020-99-3-270-273

Обзорная статья

(С РОСЛАВЦЕВА С.А., 2020

Рославцева С.А.

\section{Современное распространение постельных клопов в мире (обзор литературы)}

\author{
ФБУН «Научно-исследовательский институт дезинфектологии» Роспотребнадзора, \\ 117246, Москва
}

\begin{abstract}
Приведены современные данные об увеличении численности постельных клопов - космополитического вида Cimex lectularius $и$ тропического вида C. heтірtеrиs в конце ХХ и начале ХХІ века в высокоразвитых странах Европы, Америке и Австралии. Клопы C. hemipterus, ранее не встречавшиеся на севере Европы, обнаружены в Швеции и в некоторых городах России; обсуждены причины этого явления. В последние годы отмечают ежегодное увеличение численности постельных клопов в мире на 100-500\%. Рассмотрено гигиеническое и эпидемическое значение постельных клопов. В организме клопов могут обитать возбудители различных инфекционных и инвазионных болезней, теоретически способные передаваться при кровососании или ингаляции. По данным, опубликованным в 2011 г., исследована возможность присутствия в организме клопов 45 видов патогенных для человека микроорганизмов. Среди них обнаружен 21 вид бактерий, 11 видов вирусов, 3 вида грибов, 6 видов простейших и 4 вида гельминтов. Показано, что клопы природных популяций из разных регионов мира были восприимчивы $к 25$ патогенам, причём пять патогенов способны размножаться в их организме. В обзоре, опубликованном в 2015 г., сообщено о возможном присутствии в организме клопов уже 65 видов патогенных для человека микроорганизмов. Интерес представляют данные о вирусе гепатита $B$ и возможном ингаляционном заражении человека этим микроорганизмом. Постельные клопы известны как провоканты аллергических реакций у человека: почти у 80\% людей зафиксированы аллергические реакции на укусы клопами. Уделено внимание появлению тропического постельного клопа в России, в частности в Санкт-Петербурге, Москве, Смоленске, Гусь-Хрустальном (Владимирская область).
\end{abstract}

Ключе в ы е слов а: обзор литературы; обыкновенный постельный клоп Ciтех lectularius; тропический постельный клоп C. heтірtеrиs; увеличение численности; распространение в мире; эпидемиологическое значение.

Для цитирования: Рославцева С.А. Современное распространение постельных клопов в мире (обзор литературы). Гигиена и санитария. 2020 ; $99(3): 270-273$. DOI: https://doi.org/10.33029/0016-9900-2020-99-3-270-273

Для корреспонденции: Рославцева Светлана Александровна, доктор биол. наук, зав. лаб. проблем дезинсекции ФБУн ниИ Дезинфектологии Роспотребнадзора, 117246, Москва. E-mail: roslavcevaca@mail.ru

Конфликт интересов. Автор заявляет об отсутствии конфликта интересов.

Финансирование. Исследование не имело спонсорской поддержки.

Поступила: 05.02 .2019

Принята к печати: 12.12 .2019

Опубликована: 20.04 .2020

Roslavtseva S.A.

Modern world distribution of bed bugs

Scientific Research Institute of the Disinfectology of Federal Service for Supervision on Consumer Rights Protection and Human Welfare, Moscow, 117246, Russian Federation

Data on the increase in the number of bed bugs (Heteroptera: Cimicidae) at the end of the XX century and the beginning of the XXI century in the highly developmental countries of Europe, America and Australia and the reasons for this phenomenon are given. In this review, the hygienic and epidemiological significance of bed bugs discussed. In the organism of bed bugs, such there were found 25 pathogens including bacteria, viruses, fungi, protozoa, helminthes, 5 of these pathogenic microorganisms can multiply in bed bugs. The interest on the hepatitis $B$ virus and the possibility of human infection with this virus by inhalation is shown. Attention is paid to the appearance of tropical bed bug in Russia, particularly in the big cities (St. Petersburg, Moscow, Smolensk).

Ke y w o rds: review of literature; common bed bug Cimex lectularius; tropical bed bug Cimex hemipterus; increase of population; world distribution; hygienic and epidemiological significance.

For citation: Roslavtseva S.A. Modern world distribution of bed bugs. Gigiena i Sanitaria (Hygiene and Sanitation, Russian journal). 2020; 99(3): 270-273. (In Russ.). DOI: https://doi.org/10.33029/0016-9900-2020-99-3-270-273

For correspondence: Svetlana A. Roslavtseva, MD, Ph.D., DSci., head of the laboratory of disinsection problems of the Scientific Research Institute of the Disinfectology of Federal Service for Supervision on Consumer Rights Protection and Human Welfare, Moscow, 117246, Russian Federation. E-mail: roslavcevaca@mail.ru

Information about the author:

Roslavtseva S.A., https://www.researcherid.com/rid/0-8624-2017; https://orcid.org/0000-0003-1684-2029

Conflict of interest. The authors declare no conflict of interest.

Acknowledgment. The study had no sponsorship.

Received: February 5, 2019

Accepted: December 12, 201

Published: April 20, 2020 


\section{Введение}

Постельные клопы (Heteroptera, Cimicidae) - одни из первых насекомых, подвергшиеся процессу синантропизации ещё на заре человечества. Широко распространены во многих странах мира два вида постельных клопов - Cimex lectularius L. и тропический вид $-C$. hemipterus (F.). В Европу C. lectularius были завезены в XI веке, а в Америку - при её массовом освоении колонистами. Оба вида - облигатные синантропы, но C. lectularius распространён на всех континентах, кроме Антарктиды, и предпочитает умеренные широты, а $C$. hemipterus обитает главным образом повсеместно в тропиках [1].

Питание постельных клопов кровью человека обусловливает их статус объектов, имеющих медицинское значение. Учёт численности постельных клопов начали проводить только в 30-х гг. XX века. Так, в Великобритании была создана Королевская комиссия по постельным клопам, которая в 1933 г. сообщила, что все дома в этой стране в большей или меньшей степени заселены клопами. С началом применения ДДТ (1940 г.) численность клопов в Великобритании и других странах резко снизилась. В середине прошлого века считалось, что проблема постельных клопов - удел слаборазвитых и развивающихся стран. Однако оказалось, что увеличение численности постельных клопов с середины 90-х гг. XX века - общемировая тенденция [2].

Так, в США первые сведения об увеличении площадей, заселённых клопами, были опубликованы в 1999 г. В штате Флорида с 1999 по 2010 г. численность клопов возросла в 10 раз. Особенно заметным рост численности клопов в США был в 2005-2007 гг. В 2007 г. клопы заселили около 80\% квартир. Количество инсектицидных обработок против клопов составляло 5 и более в год [3]. В последние годы в США борьба с клопами занимает $76 \%$ от общего объёма мероприятий по борьбе с синантропными насекомыми, оставшиеся $17 ; 6$ и $1 \%$ приходятся на борьбу с муравьями, тараканами и термитами соответственно [4].

Примерно в это же время начался резкий подъём численности постельных клопов в Австралии: количество инсектицидных обработок против клопов возросло в 45 раз. В Лондоне (Великобритания) с середины 90-х гг. XX века количество обработок в борьбе с этими насекомыми ежегодно увеличивается на 24,7\%. С 1999 г. возрастает численность постельных клопов в Швейцарии (Цюрих), а к 2007 г. она увеличилась на $40 \%$. Резкое увеличение численности клопов отметили в этом городе в 2010 г. - более $50 \%$ помещений оказались заселёнными этими насекомыми $[5,6]$.

O возросшей важности этой проблемы можно судить по тому факту, что на пяти международных конференциях «Вредные организмы в урбанизированных биоценозах» в период 1992-2005 гг. не было представлено ни одного доклада или сообщения, касающихся постельных клопов и мер борьбы с ними. Однако уже на 6-й (Венгрия, июль 2008 г.), 7-й (Бразилия, июль 2011 г.), 8-й (Швейцария, июль 2014 г.) и 9-й (Великобритания, Бирмингем, июль 2017 г.) конференциях состоялись специальные симпозиумы, на которых были заслушаны доклады, посвящённые увеличению численности клопов и возможным путям решения проблемы борьбы с ними.

В СССР, а затем и в России численность клопов в разные годы колебалась. Наблюдения за численностью C. lectularius были начаты в Москве с середины 30-х гг. XX века. В 19501960-е гг. в СССР отмечали значительное распространение этих насекомых, но за период 1960-1987 гг. объём дезинсекционных работ по борьбе с клопами снизился. В Москве в период 1989-1997 гг. почти не осталось объектов, заселённых этими насекомыми. В целом в России численность постельных клопов оставалась низкой почти до конца XX века, но в начале XXI века отметили тенденцию к её резкому уве- личению [7]. В письме Роспотребнадзора № 01/8346-16-27 от 04.07.2016 г. указано, что в России с 2014 по 2015 г. увеличились в 2,3 раза площади, обработанные против клопов (2014 г. - 7,1 млн м², а в 2015 г. - 6,2 млн м²).

\section{Потенциальное эпидемиологическое значение постельного клопа}

Ранее считалось, что постельный клоп не имеет эпидемиологического значения. В течение двух последних десятилетий происходит повсеместное ежегодное увеличение численности этих насекомых, что к настоящему времени стало общемировой проблемой. Поэтому в настоящее время уделяется повышенное внимание выяснению эпидемиологического статуса этих насекомых.

Согласно имеющимся данным, в настоящее время почти у $80 \%$ людей зафиксированы различные аллергические реакции на укусы клопами [8]. Слюна клопов, выделяемая при укусах, может вызывать различные аллергические проявления у людей, такие как зуд, жжение, покраснение кожи, образование папул, дерматит, импетиго, эктима, лимфангит, фолликулит, диарея, летаргия вплоть до анафилактического шока и астматического криза.

При интенсивном расчёсывании мест укусов на коже могут возникать гнойнички - ворота для вторичной инфекции. Клопы также являются серьёзным беспокоящим фактором, лишающим людей нормального сна и отдыха [1].

При высокой численности клопов их укусы часто являются причинами железодефицитной анемии, особенно у детей, а также вызывают снижение иммунитета $[9,10]$. Нимфы клопов могут проникать в ушной канал, вызывая дерматологические реакции - синдром Гуль-Страсса [11]. Некоторые аллергические реакции у людей относятся к $\mathrm{IgE}$-опосредованной гиперсенсибилизации к нитрофориновому белку (cNP), известному как аллерген на укусы клопами [12].

В организме клопов могут обитать возбудители различных инфекционных и инвазионных болезней, теоретически способные передаваться через слюну при кровососании и через экскременты. При кровососании патоген попадает сразу в кровь [13].

Согласно имеющимся материалам, посвящённым роли постельных клопов как резервуаров и переносчиков патогенов, к настоящему времени рассмотрена восприимчивость клопов из различных природных популяций к 45 патогенам человека (вирусы, риккетсии, бактерии, грибы, простейшие и гельминты). К 23 из них клопы оказались восприимчивыми. Ниже приведён список этих организмов (в скобках указано вызываемое ими заболевание) [цитировано по: Delaunay et al., 2011] [14]:

- бактерии - Bacillus anthracis (сибирская язва); Mycobacterium leprae (лепра); Mycobacterium tuberculosis (туберкулёз); Coxiella burneti (лихорадка Ky); Francisella tularensis (туляремия); Brucella melitensis (бруцеллёз); Salmonella typhi (брюшной тиф); Staphylococcus aureus (септицемия); Streptococcus pneumoniae (внебольничная пневмония); Yersinia pestis (чума);

• вирусы - гепатит В, оспа; жёлтая лихорадка;

- грибы - Aspergillus flavus и другие виды из этого рода, Penicillium spp. и Scopulariopsis spp.;

- простейшие - Trypanosoma cruzi (болезнь Чагаса); Leishmania tropica, L. donovani, L. braziliensis (лейшманиозы);

- гельминты - Brugiamalayi и Wuchereria bancrofti (филяриозы); Mansonella ozzardi (мансонеллёз).

Согласно данным лабораторных исследований, установлена возможность передачи трёх патогенов при питании заражённых клопов на животных, пять из указанных патогенов при инъекции лабораторным животным могли размножаться в их организме. Многие возбудители заболеваний могут 
Рославцева С.A.

Современное распространение постельных клопов в мире (обзор литературы)

DOI: https://dx.doi.org/10.33029/0016-9900-2020-99-3-270-273

Обзорная статья

выделяться с экскрементами клопов и длительное время оставаться жизнеспособными в них. В организме клопов из природных популяций обнаружены еще 15 патогенных организмов и могут быть найдены, по разным данным, Bartontla quintana [15]. Интересен недавно установленный факт способности постельного клопа $C$. lectularius являться переносчиком возбудителя трипаносомоза [16].

Также вероятным кандидатом на передачу от клопов человеку из вышеупомянутых возбудителей считается вирус гепатита В. Несмотря на то что передача его человеку клопами при укусах не доказана, существует риск заражения ингаляционным путём при систематическом вдыхании содержащих вирус сухих частиц экскрементов клопов [17, 18].

В большинстве случаев для подтверждения роли постельных клопов в передаче того или иного патогена требуется проведение значительных дополнительных исследований. Тем не менее приведённые данные следует иметь в виду при массовом заселении помещений постельными клопами.

Аналогичные материалы были приведены в работе A.A. Girault в 2015 г. [19]. Показано, что клопы играют определённую роль в передаче таких патогенов, как Rickettsia parkeri [13], Bartonella quintana [15] и Trypanosoma cruzi [16].

Имеются данные о том, что постельные клопы были вовлечены в передачу резистентного к метициллину золотистого стафилококка Staphylococcus aureus и резистентных к ванкомицину бактерий Enterococcus faecium у некоторых пациентов, госпитализированных в Ванкувере (Канада) [20].

В большинстве случаев для подтверждения роли постельных клопов в передаче того или иного патогена требуется проведение значительных дополнительных исследований. Тем не менее приведённые данные следует иметь в виду при массовом заселении помещений постельными клопами.

\section{Причины увеличения численности постельных клопов в начале XXI века}

Чем можно объяснить подобное увеличение численности этих насекомых? Представитель ВО3 С. Boase [21] считает, что этот всплеск численности клопов связан с тремя группами причин - социальными проблемами человека, изменением окружающей среды и применением инсектицидов.

$\mathrm{K}$ первой группе причин относятся увеличение продажи в последние годы вещей, бывших в употреблении («секондхенд»), активизация туризма и миграции из стран Ближнего Востока и Балкан, передвижение бизнесменов и их товаров.

Вторая группа причин включает факторы воздействия окружающей среды, в частности увеличение круглогодично отапливаемых помещений, что повышает репродуктивную способность клопов.

Третья группа причин включает изменение технологий и ассортимента применяемых инсектицидов. Так, в 1980-е гг. для борьбы с синантропными тараканами применяли контактные инсектициды широкого спектра действия, используя метод опрыскивания. Эти обработки характеризовались наличием остаточного действия и, кроме тараканов, уничтожали также постельных клопов. Переход на специальные инсектициды для борьбы с синантропными тараканами, их применение в инсектицидных приманках, гелях и приманочных станциях способствовали размножению клопов и заселению ими помещений. Кроме того, сменился ассортимент инсектицидов, снизилось применение фосфорорганических инсектицидов, обладающих овицидным действием (убивающих яйца клопов). Кроме того, увеличению численности клопов способствовало формирование популяций, резистентных к инсектицидам различного химического строения [2]. Так, в настоящее время во многих европейских странах, даже в Швейцарии; в Америке, особенно в США; в Австралии, Юго-Восточной Азии распространены популяции постельных клопов, резистентные к хлорорганическим и фосфорорганическим соединениям, производным карбаминовой кислоты, пиретроидам.

Начало массового распространения постельных клопов C. lectularius L. в современное время относят к середине $90-\mathrm{X}$ гг. XX века. В настоящее время 75\% домов, апартаментов, отелей, мотелей заселено клопами. Проведён опрос 2088 человек из 50 штатов США (бизнесменов и туристов) по поводу обнаружения постельных клопов в отелях и мотелях. По данным бизнесменов, в 35\% случаев проживания в отелях и мотелях установлено наличие клопов, по данным туристов в 28\% случаев [22].

В настоящее время энтомологов и медицинских работников волнует вопрос распространения не только обыкновенных постельных клопов C. lectularius, но и тропических постельных клопов C. hemipterus. В 1995-1996 гг. тропические постельные клопы были собраны в деревнях Танзании; в 2001-2003 гг. - на Шри-Ланке и в Южной Корее. В Малайзии тропические постельные клопы были обнаружены в 38 из 185 городов [23].

Клоп C. hemipterus стабильно обитает в тропиках и субтропических регионах Земли, включая штат Флорида (США), где он был впервые обнаружен в 1938 г. После долгого перерыва в октябре 2016 г. этот вид был вновь найден во Флориде [24].

Тропические клопы найдены на севере Австралии. Первый раз тропический постельный клоп был обнаружен в этом регионе в 1998 г., а впоследствии - в 2003 г. [25].

Данные о распространении в мире этих двух видов клопов были обобщены A. Zorrilla-Vaca и соавт. [26], клопы C. lectularius обнаружены в 24 странах, клопы C. hemipterus - в 19 странах, в основном тропической и субтропической областей. Оба вида клопов - C. lectularius и C. hemipterus - одновременно обитают в Таиланде, некоторых странах Африки, Австралии и в штате Флорида (США).

При проведении анализа литературных данных установлено, что до недавнего времени клопы C. hemipterus главным образом обитали между 30-ми параллелями северной и южной широты. Новые данные расширяют этот список в связи с обнаружением тропических клопов даже в России [27-29].

Специалистами Московского городского центра дезинфекции было опубликовано сообщение о многочисленных сборах на объектах столицы клопов C. hemipterus в количестве, чуть ли не превышающем таковое клопов C. lectularius $[27,28]$. Так, по данным этих авторов, тропический постельный клоп впервые найден во многих районах Москвы в 2015-2016 гг.; в пяти районах Санкт-Петербурга, в Московской области, Смоленске и в Саранске - в 2016 г. В Санкт-Петербурге отмечена необычная активность особей этого вида в светлое время суток. По мнению Д.Ф. Гапона [29], в Санкт-Петербурге и в Москве в местах, где были найдены клопы $C$. hemipterus, отсутствовали клопы $C$. lectularius. Автор утверждает, что во всех пунктах сбора тропических постельных клопов они были устойчивы ко всем инсектицидам, применяемым для борьбы c C. lectularius, но не приводит фактические данные о величинах средних концентраций инсектицидов, вызывающих гибель 95\% экспериментальных особей, или доле устойчивых к инсектицидам особей в популяции. Автор предполагает, что можно ожидать благополучное переживание в России тропических постельных клопов в зимний период в отапливаемых помещениях; причём этот вид будет активно распространяться, вытесняя клопа C. lectularius.

Сотрудники ФБУН НИИ Дезинфектологии проверили видовую принадлежность популяций постельных клопов, собранных в Москве, Астрахани и Смоленске в 2012-2013 гг. и культивируемых в инсектарии института. Эти популяции 
относятся к виду C. lectularius. Популяции, собранные в 2017-2018 гг. на разных объектах Москвы, Московской области (Мытищи), Владимирской области (две популяции из г. Гусь-Хрустальный), также относились к этому виду, но клопы, присланные нам из Санкт-Петербуга, обнаруженные в Москве в квартирах около метро «Автозаводская» и Чертанове, как и две популяции из г. Гусь-Хрустальный, были отнесены к виду $C$. hemipterus.

\section{Заключение}

Резкое увеличение численности постельных клопов в мире и в нашей стране, появление нового вида (C. hemipterus) в России и наличие данных о формировании мультирезистентных популяций повышает эпидемический статус этих насекомых и требует разработки средств и новых технологий их применения для борьбы с постельными клопами.

\section{Литература (пп. 3-6, 8-25 см. References)}

1. Тарасов В.В. Медицинская энтомология. М.: Издательство Московского университета; 1996. 352 с

2. Рославцева С.А., Алексеев М.А., Кривонос К.С. Синантропные клопы - биология, численность, эпидемиологическое значение. В кн.: Современные вопросы дезинфектологии. Медииинская дезинсекция: объекты, средства, резистентность иленистоногих к инсектоакарицидам. М.: ФБУН «НИИДезинфектологии» Роспотребнадзора; 2017: $173-88$.

7. Богданова Е.Н., Рославцева С.А., Слободин А.З. Постельные клопы (Hemiptera: Cimicidae). Современная ситуация в Российской Федерации и дезинсекционные мероприятия против них. Дезинфекционное дело. 2005; 4: 55-9.
26. Хряпин Р.А., Юнаков П.А., Пугаев С.Н., Матвеев А.А. Новые, необычные и редко встречающиеся объекты медицинской дезинсекции в жилых и производственных помещениях г. Москвы. Дезинфекционное дело. 2016; 4 (98): 39-42.

27. Хряпин Р.А., Капустин В.Ю., Матвеев А.А. Практический опыт борьбы с тропическим постельным клопом Cimex himipterus на объектах города Москвы и Московской области. Дезинфекционное дело. 2019; 3 (109): 40-6.

28. Гапон Д. Первые находки тропического постельного клопа $C$. hemipterus (Heteroptera: Cimicidae) в России. Zoosystematica Rossica. 2016; 25 (2): 239-42.

\section{References}

1. Tarasov V.V. Medical entomology [Meditsinskaya entomologiya]. Moscow: Izdatelstvo Moskovskogo gosudarstvennogo universiteta; 1996. 352 p. (in Russian)

2. Roslavtseva S.A., Alekseev M.A., Krivonos K.S. Synanthropic bugs (Heteroptera, Triatomidae, Cimicidae) - their biology, number, and epidemiological significance [Sinantropnyye klopy (Heteroptera, Triatomidae, Cimicidae) - biologiya, chislennost, epidemiologicheskoye znacheniye]. In: Contemporary issues in disinfectology. Medical disinsection: subjects, formulations, arthropod resistance to insectoacaricides [Sovremenniye voprosy dezinfektologii. Meditsinskaya desinsektsiya: ob'ekty, sredstva, rezistentnost chlenistonogikh $k$ insektoakaritsidam]. Moscow: Scientific Research Disinfectology Institute; 2017: 173-87. (in Russian)

3. White I. An overview of bed bug (Hemiptera: Cimicidae) treatment in Unites States: using science to create progressive protocols. In: M.P. Davies, C. Pfeiffer, and W.H. Robinson (eds.). Proceedings of the $9^{\text {th }}$ International Conference on Urban Pests, July 9-12, 2017, Birmingham, UK. Uckfield, East Sussex: Pureprint Group; 2017: 103-11.

4. Potter M.F., Penu J.M., Hu W. Bed bug, hotels and travelers; attitudes and implications. In: M.P. Davies, C. Pfeiffer, and W.H. Robinson (eds.). Proceedings of the $9^{\text {th }}$ International Conference on Urban Pests, July 9-12, 2017, Birmingham, UK. Uckfield, East Sussex: Pureprint Group; 2017: 67-75.

5. Mueller G., Luescher I.L., Schmidt M. Temporal changes in the incidence of household arthropod pests in Zurich, Switzerland. In: W.H. Robinson and D. Bajomi (eds.). Proceedings of the $6^{\text {th }}$ International Conference on Urban Pests, July 13-16, 2008, Budapest, Hungary. Veszprém, Hungary: OOK-Press Kft.; 2008: 124-7.

6. Mueller G., Luescher I.L., Schmidt M. New data on the incidence of household arthropod pests and new invasive pests in Zurich (Switzerland). In: W.H. Robinson and A.E.C. Campos (eds.). Proceedings of the $7^{\text {th }}$ International Conference on Urban Pests, 7-10 August, 2011, Ouro Preto, Brazil. São Paulo, SP, Brazil: Instituto Biológico; 2011: 99-104.

7. Bogdanova E.N., Roslavtseva S.A., Slobodin A.Z. Bed bugs (Hemiptera: Cimicidae). Contemporary situation in Russian Federation and disinsection measures against them. Dezinfektsionnoye delo [Disinfection Affairs]. 2005; 4: 55-8. (in Russian)

8. Paulke-Korinek M., Széll M., Laferl H., Auer H., Wenisch C. Bed bugs cause severe anaemia in adults. Parasitol Res. 2012; 110 (6): 2577-9.

9. Sabou M., Imperiale D.G., Andrès E., Abou-Bacar A., Foeglé J., Lavigne T. et al. Bed bugs reproductive life cycle in the clothes of a patient suffering from Alzheimer's disease results in iron deficiency anemia. Parasite. [Electronic resource]. 2013; 20: 16. DOI: https://10/1051/parasite/2013018.

10. DeShazo R.D., Feldlaufer M.F., Mihm Jr. M.C., Goddard J. Bullous reactions to bedbug bites reflect cutaneous vasculitis. Am J Med. 2012; 125 (7): 688-94.

11. Divjan A., Price J.B., Acosta L.M., Rundle A., Goldstein I., Jacobson J. et al. Development of IgE against a Cimex lectularius allergen after being bitten by bed bugs was common among children in NYC. J Allergy Clin Immunol. [Electronic resource]. 2014; 133 (2): Suppl. P. AB164. DOI: http://dx.doi.org/10.1016/j.jaci.2013.12.593.

12. Goddard J., Valera-Stokes A., Smith W., Edwards K. Artificial infection of the bed bugs with Rickettsia parkeri. J Med Entomol. 2012; 49 (4): 922-6.
13. Delaunay P., Blanc V., Del Giudice P., Levy-Bencheton A., Chosidow O., Marty P. et al. Bedbugs and infectious diseases. Clin Infect Dis. 2011; 52 (2): $200-10$

14. Leulmi H., Bitam I., Berenger J.M., Lepidi H., Rolain J.M., Almeras L. et al. Competence of Cimex lectularius bed bugs for the transmission of Bartonella quintana, the agent of trench fever. PLoS Negl Trop Dis. [Electronic resource]. 2015; 9 (5): e0003789. DOI: https://10.1371/journal. pntd.0003789.

15. Salazar R., Castillo-Neyra R., Tustin A.W., Borrini-Mayorí K., Náquira C., Levy M.Z. Bed bugs (Cimex lectularius) as vectors of Trypanosoma cruzi. Am J Trop Med Hyg. 2015; 92 (2): 331-5.

16. Blow J.A., Turell M.J., Silverman A.L., Walker E.D. Stercorarial shedding and transstadial transmission of hepatitis B virus by common bed bugs (Hemiptera: Cimicidae). J Med Entomol. 2001; 38 (5): 694-700.

17. El-Masry S.A., Kotkat A.M. Hepatitis B surface antigen in Cimex lectularius. J Egypt Publ Health Assoc. 1990; 65 (3-4): 229-36.

18. Girault A.A. The present status of the bedbug in transmission of human diseases. J Am Med Assoc. 2015; 67 (2): 85-7.

19. Lowe C.F., Romney M.G. Bedbugs as vectors for drug-resistant bacteria [Letter]. Emerg Infect Dis. 2011; 17 (6): 1132-4.

20. Boase C. Bed bugs (Hemiptera: Cimicidae): an evidence-based analysis of the current situation. In: W.H. Robinson and D. Bajomi (eds.). Proceedings of the 6th International Conference on Urban Pests, July 13-16, 2008, Budapest, Hungary. Veszprém, Hungary: OOK-Press Kft.; 2008: 7-14.

21. Potter M.F., Penu O.P., Hu W.S. Bed bud, hotels and travelers; attitudes and implications. In: M.P. Davies, C. Pfeiffer, and W.H. Robinson (eds.). Proceedings of the 9th International Conference on Urban Pests, July 9-12, 2017, Birmingham, UK. Uckfield, East Sussex: Pureprint Group; 2017: 67-73.

22. Koganemaru R., Miller D.M. The bed bug problem: Past, present and future control methods. Pest Biochem Physiol. 2013; 106 (3): 177-89.

23. Campbell B.E., Koehler P.G., Lyle J.B., Baldwin R.W. Recent documentation of the tropical bed bug Cimex hemipterus (Hemiptera: Cimicidae) in Florida since the common bed bug resurgence. Fla Entomol. 2016; 99 (3): 549-51.

24. Lilly D.G., Dang K., Doggett S.L., Webb C.E. Studies on insecticide resistance in Australian bugs Cimex spp. (Hemiptera: Cimicidae). In: M.P. Davies, C. Pfeiffer, and W.H. Robinson (eds.). Proceedings of the $9^{\text {th }}$ International Conference on Urban Pests, July 9-12, 2017, Birmingham, UK. Uckfield, East Sussex: Pureprint Group; 2017: 281-9.

25. Zorrilla-Vaca A., Silva-Medina M.M., Escandon-Vargas K. Bedbugs, Cimex spp. Their current world resurgence and healthcare impact. Asian Pac J Trop Dis. 2015; 5 (5): 342-52.

26. Khryapin R.A., Yunakov P.A., Pugayev S.N., Matveev A.A. The new, unusual and seldom found subjects to medical disinsection from residential and production rooms of Moscow. Dezinfektsionnoye delo [Disinfection Affairs]. 2016; 4 (98): 39-42. (in Russian)

27. Khryapin R.A., Kapustin V.Ju., Matveev A.A. Practical experience control of the the tropical bed bug $C$. hemipterus $F$, at the facilites of the city of Moscow and Moscow region. Dezinfektsionnoye delo [Disinfection Affairs]. 2019; 3 (109): 40-6. (in Russian)

28. Gapon D.A. First records of the tropical bed bug C. hemipterus (Heteroptera: Cimicidae) from Russia. Zoosystematica Rossica. 2016; 25 (2): 239-42. (in Russian) 